\title{
Article \\ Soil Water Content Prediction Using Electrical Resistivity Tomography (ERT) in Mediterranean Tree Orchard Soils
}

\author{
José A. Acosta ${ }^{1, *}$, María Gabarrón ${ }^{1}$, Marcos Martínez-Segura ${ }^{2}{ }^{\circledR}$, Silvia Martínez-Martínez ${ }^{1}$, Ángel Faz ${ }^{1}$, \\ Alejandro Pérez-Pastor ${ }^{1}$ (D), María Dolores Gómez-López ${ }^{1}$ (D) and Raúl Zornoza ${ }^{1}$ (D) \\ 1 Departamento de Ingeniería Agronómica, Universidad Politécnica de Cartagena, Paseo Alfonso XIII, 48, \\ 30230 Cartagena, Spain; maria.gabarron@upct.es (M.G.); silvia.martinez@upct.es (S.M.-M.); \\ angel.fazcano@upct.es (Á.F.); alex.perez-pastor@upct.es (A.P.-P.); lola.gomez@upct.es (M.D.G.-L.); \\ raul.zornoza@upct.es (R.Z.) \\ 2 Departamento de Ingeniería Minera y Civil, Universidad Politécnica de Cartagena, Paseo Alfonso XIII, 52, \\ 30230 Cartagena, Spain; marcos.martinez@upct.es \\ * Correspondence: ja.acosta@upct.es; Tel.: +34-968-32-5667
}

check for updates

Citation: Acosta, J.A.; Gabarrón, M.; Martínez-Segura, M.;

Martínez-Martínez, S.; Faz, Á.; Pérez-Pastor, A.; Gómez-López, M.D.; Zornoza, R. Soil Water Content

Prediction Using Electrical Resistivity Tomography (ERT) in Mediterranean Tree Orchard Soils. Sensors 2022, 22, 1365. https://doi.org/10.3390/ s22041365

Academic Editor: Ivan Andonovic

Received: 18 November 2021

Accepted: 8 February 2022

Published: 10 February 2022

Publisher's Note: MDPI stays neutral with regard to jurisdictional claims in published maps and institutional affiliations.

Copyright: (C) 2022 by the authors. Licensee MDPI, Basel, Switzerland. This article is an open access article distributed under the terms and conditions of the Creative Commons Attribution (CC BY) license (https:// creativecommons.org/licenses/by/ $4.0 /$ )

\begin{abstract}
Water scarcity in arid and semiarid regions poses problems for agricultural systems, awakening special interest in the development of deficit irrigation strategies to improve water conservation. Toward this purpose, farmers and technicians must monitor soil water and soluble nutrient contents in real time using simple, rapid and economical techniques through time and space. Thus, this study aimed to achieve the following: (i) create a model that predicts water and soluble nutrient contents in soil profiles using electrical resistivity tomography (ERT); and (ii) apply the model to different woody crops under different irrigation regimes (full irrigation and regulated deficit irrigation (RDI)) to assess the efficiency of the model. Simple nonlinear regression analysis was carried out on water content and on different ion contents using electrical resistivity data as the dependent variable. A predictive model for soil water content was calibrated and validated with the datasets based on exponential decay of a three-parameter equation. Nonetheless, no accurate model was achieved to predict any soluble nutrient. Electrical resistivity images were replaced by soil water images after application of the predictive model for all studied crops. They showed that under RDI situations, soil profiles became drier at depth while plant roots seemed to uptake more water, contributing to reductions in soil water content by the creation of desiccation bulbs. Therefore, the use of ERT combined with application of the validated predictive model could be a sustainable strategy to monitor soil water evolution in soil profiles under irrigated fields, facilitating land irrigation management.
\end{abstract}

Keywords: electrical resistivity; tomography; regulated deficit irrigation; soil moisture; nonlinear regression analysis

\section{Introduction}

More than one hundred countries in the world are under conditions of aridity and semi-aridity. Africa is the continent most damaged by desertification followed by Asia, Latin America and the Caribbean. On the European continent, Mediterranean countries that comprise Spain, Portugal, Italy, Turkey and Greece make up one of the four zones determined by the UN convention as being affected by desertification [1]. Hence, water scarcity in arid and semiarid regions poses widespread problems for agricultural systems, awakening special interest in the development of efficient irrigation strategies that facilitate water saving [2]. The adoption of new strategies to optimize irrigation by reducing water and energy consumption will be essential to maintain agricultural activity in desertificationaffected regions. With regard to this, the Segura basin (SE Spain) has a water structural deficit of about $460 \mathrm{hm}^{3}$ per year, making it the region with the greatest water deficit in the European Union; it is also the most regulated basin in Europe with the highest water use 
efficiency [3]. Despite its water scarcity, productive agriculture is developed there whose production is mainly exported to EU state members. Hence, irrigation of the Segura basin leads in demand for the proportion of water it needs.

Currently, special interest has arisen for the development of regulated deficit irrigation (RDI) strategies that strive to significantly reduce irrigation water content without affecting production or crop quality [4-6]. RDI is based on reduction of water supply during noncritical periods, covering water needs during critical periods and maximizing at the same time production per unit of applied water [7]. Nonetheless, its success greatly depends on adequate application of the water deficit. RDI also requires continuous and precise control of the status of plants and soils in order to adjust water supplies at every crop phenological period [8]. Consequently, there is a need to develop rapid, economical and easy-to-use tools so that farmers and technicians can continuously monitor soil water content in real time using soil profiles.

Methods for soil moisture determination are usually based on direct measures which consist of weighing soil before and after oven-drying, or using in situ probes. Recent studies have demonstrated the potential use of some geophysical techniques, such as electrical resistivity tomography (ERT), for soil characterization and particularly for soil moisture estimation [9-12]. While traditional techniques seem restricted to the rhizosphere area and provide data from a single point of measure, the ERT technique offers continuous measurements at multiple lengths and depths. The ERT technique is rapid, cost-effective and does not cause strong perturbations in soils [13]. This approach is based on the relationship between the behavior of a soil property and a real resistivity measure using regression models. Polynomial functions or power functions are usually used for a large range of moisture changes, typically from full saturation to dry soil states [14,15]. However, in some particular cases, this relationship can follow a linear model, as reported by Michot et al. [11]. Thus, these results highlight the large variability of data and the complexity in developing predictive models using ERT.

The ERT technique is based on the use of electric current to assess electrical properties of the subsurface (e.g., resistivity, conductivity). A set of four electrodes driven into the soil injects currents (two electrodes) and measures potential differences (two electrodes) simultaneously. The interactions of these currents with subsurface materials act differently depending on characteristics of the subsurface, allowing geoelectric profiles to be calculated [16]. Thus, soil electrical resistivity mainly involves constant physical properties of the soil, such as clay content, but it also involves variable properties such as soil water content, soil water electrical conductivity and temperature [11,17].

Electrical profiling using ERT requires many electrodes connected to a switch box by a cable. This allows multiple apparent resistivity measurements to be made using different electrodes. This system is called a multi-electrode system, or sometimes a multi-channel system [18]. Subsequently, resistivity values are obtained from the inversions of apparent resistivity values measured in the field $[19,20]$.

Based on the aforementioned approach, we hypothesized that the ERT method could replace moisture probes in woody crops during the vegetation period using a moistureresistivity model. Thus, an experiment was set up in different commercial tree orchards where full irrigation and RDI were applied over a period of two years. The objectives of the experiment were the following: (i) to calibrate a model that allows users to predict water and soluble nutrient contents in soil profiles of different woody crops using ERT; (ii) to validate the model in woody crop orchards under different irrigation regimes in order to assess the efficiency of the model; and (iii) to assess differences in soil water content using soil profiles from different irrigation schedules in different crops. We hypothesized that $\varrho$ values derived from ERT could be related to soil moisture and some nutrient contents by the use of nonlinear regression analysis, thereby calibrating and validating a suitable model. The application of this model would permit users to depict soil profile images with estimated values of soil, water and nutrient concentrations for rapid and cost-efficient monitoring of these properties by end-users. 


\section{Materials and Methods}

\subsection{Study Area}

The study was conducted at three commercial farms located in Campotéjar (Region of Murcia, Spain) where different crops were selected. The first farm $\left(38^{\circ} 11^{\prime} \mathrm{N} ; 1^{\circ} 18^{\prime} \mathrm{W}\right)$ had Saturn peach (Prunus persica var. platycarpa) and table grape (Vitis vinifera) crops. The $P$. persica var. platycarpa crop had an extension of $4752 \mathrm{~m}^{2}$, with 288 trees at spacings of $5.5 \mathrm{~m}$ between rows and $3.5 \mathrm{~m}$ between trees within the same row; the $V$. vinifera crop had an extension of $3520 \mathrm{~m}^{2}$, with 252 trees at spacings of $3.5 \mathrm{~m}$ between rows and $3.0 \mathrm{~m}$ between trees within the same row. The second farm $\left(38^{\circ} 17^{\prime} \mathrm{N} ; 1^{\circ} 23^{\prime} \mathrm{W}\right.$ ) had peach trees (Prunus persica), with an extension of $4725 \mathrm{~m}^{2}$, with 270 trees at spacings of $5.5 \mathrm{~m}$ between rows and $3.5 \mathrm{~m}$ between trees within the same row. The third farm $\left(38^{\circ} 13^{\prime} \mathrm{N} ; 1^{\circ} 22^{\prime} \mathrm{W}\right)$ was cultivated with nectarine trees (Prunus persica var. nucipersica), with an extension of $670,000 \mathrm{~m}^{2}$, with 31,900 trees at spacings of $6 \mathrm{~m}$ between rows and $3.5 \mathrm{~m}$ between trees within the same row (Figure 1).

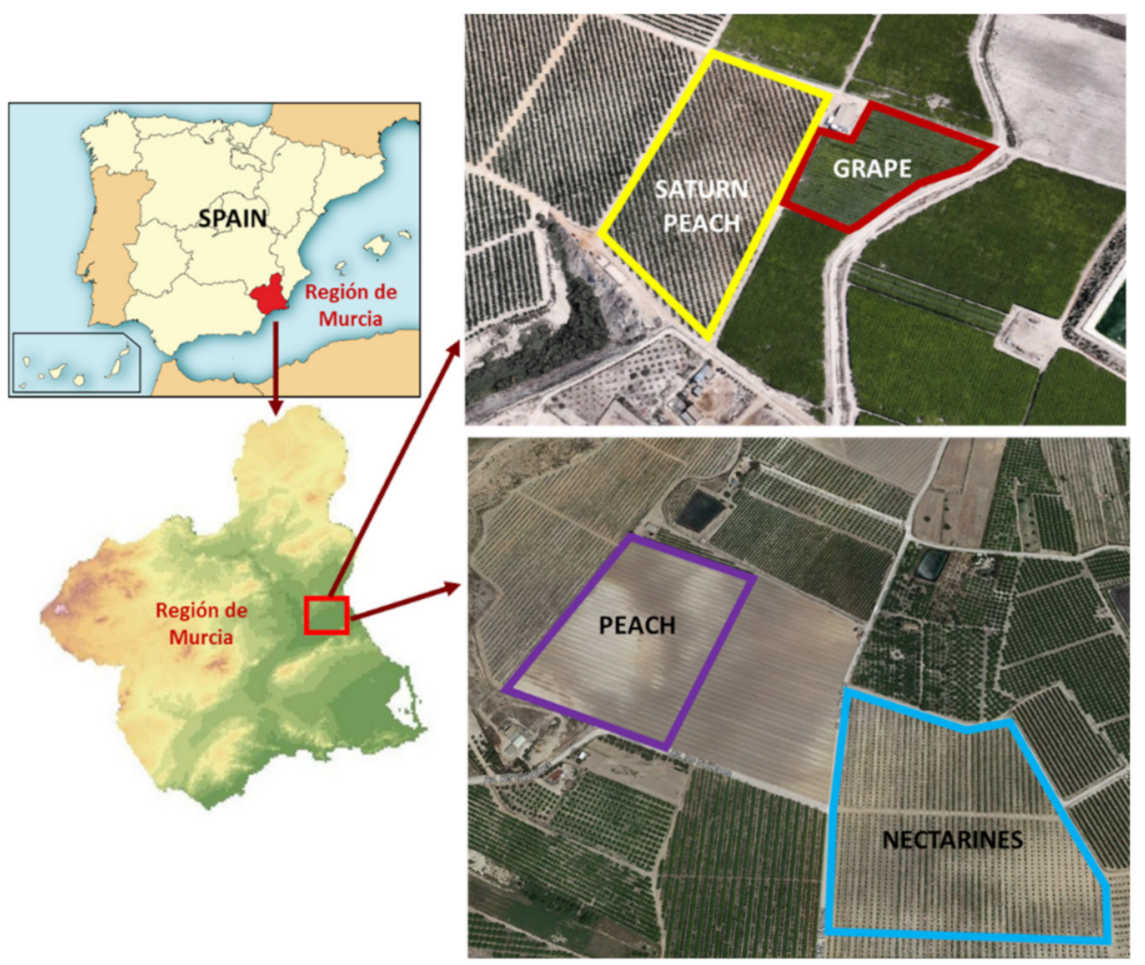

Figure 1. Locations of the selected orchards.

The climate of the area is semiarid Mediterranean with a mean annual temperature of $18^{\circ} \mathrm{C}$ and a mean annual precipitation of $270 \mathrm{~mm}$. Potential evapotranspiration surpasses $1200 \mathrm{~mm}$ per year. The geology of the area is represented by Neogene and Quaternary marls [21] and soils are classified as Calcaric Regosols [22] with soil depths of Ap:0-45 cm and C:>45 cm for Saturn peach; Ap:0-35 cm and C:>35 cm for grape; Ap:0-40 cm and $C:>40 \mathrm{~cm}$ for peach; and Ap:0-50 cm and C:>50 cm for nectarine. The main soil characteristics for all crops are shown in Table 1. Customary cultural practices (e.g., weed control, fertilization, pruning, fruit thinning and banding) are carried out by the technical departments of these commercial orchards.

A drip irrigation system was installed, with two lines per tree row and nine pressurecompensated emitters $\left(1.6 \mathrm{~L} \mathrm{~h}^{-1}\right)$ per tree placed at every $75 \mathrm{~cm}$. Irrigation was scheduled weekly at nights. The frequency of irrigation varied according to evaporative demand, which was 1 to 2 times per week in winter, 2 to 7 times per week in spring and autumn, and 7 to 14 times per week in summer. All crops were irrigated with well water having an electrical conductivity ranging between 2.5 and $2.8 \mathrm{dS} \mathrm{m}^{-1}$. We applied two different 
irrigation treatments as follows: (1) a control group (CT) where trees were irrigated to satisfy the maximum water requirement of each crop type; and (2) a regulated deficit irrigation (RDI) group where trees were irrigated at $100 \%$ of the crop water requirement except for the post-harvest period in P. persica var. platycarpa, the post-veraison period in $V$. vinifera and the pre-harvest and post-harvest periods in P. persica var. nucipersica, which were irrigated at 50\% CT; the aim of this was not to surpass the threshold of the stem water potential of $-2 \mathrm{MPa}$. The total crop water needs were estimated as the product of reference crop evapotranspiration (ET0) and the crop coefficients (between 0.25 and 0.55) proposed by the Agricultural Information System of Murcia (http:/ / siam.imida.es, 1 March 2015) for this area, adjusted for tree size [23]. The experiment was set as a randomized design with three replications per treatment. Each replicate had three adjacent tree rows and fifteen trees per row. All measurements and samplings were carried out in the central row of each replicate.

Table 1. Main soil properties for the different crops used in this study.

\begin{tabular}{ccccc}
\hline & \multicolumn{3}{c}{ Crops } \\
\hline Soil Properties & Saturn Peach & Table Grape & Peach & Nectarine \\
\hline Bulk density $\left(\mathrm{g} \mathrm{cm}^{-3}\right)$ & 1.23 & 1.17 & 1.17 & 1.32 \\
pH & 7.90 & 7.76 & 7.79 & 8.02 \\
Electrical conductivity $1: 5\left(\mathrm{mS} \mathrm{cm}^{-1}\right)$ & 3.42 & 2.43 & 4.56 & 1.34 \\
Organic carbon $\left(\mathrm{g} \mathrm{kg}^{-1}\right)$ & 9.1 & 12.8 & 10.1 & 12.8 \\
Total nitrogen $\left(\mathrm{g} \mathrm{kg}^{-1}\right)$ & 1.05 & 1.16 & 0.94 & 1.42 \\
CaCO $(\%)$ & 43 & 46 & 33 & 56 \\
Clay $(\%)$ & 10 & 15 & 16 & 13 \\
Silt $(\%)$ & 56 & 56 & 24 & 59 \\
Sand $(\%)$ & 34 & 29 & 60 & 28
\end{tabular}

\subsection{ERT Methodology}

The combination of electrical sounding and profiling methods in a single process (2D resistivity imaging) allows the ERT method to provide information about lateral and vertical resistivity changes along a soil profile [24,25]. Apparent resistivity measurements were obtained using a computer-controlled multielectrode system consisting of a Syscal-R1 switch resistivimeter (IRIS Instruments, 2001) connected to 36 stainless steel electrodes spaced $30 \mathrm{~cm}$ from each other. The electrodes were georeferenced using a GPS unit, allowing characterization of the soil to a depth of $2 \mathrm{~m}$ (Figure 2). Connections between the resistivimeter and electrodes were made using a multicore cable and takeout clips for galvanic coupling of the electrodes to the ground. The datasets were acquired using a Wenner-Schlumberger electrode array due to its high signal-to-noise ratio and good vertical resolution [21].

Campaigns of ERT were carried out during the summer periods of 2015 and 2016 (July-August) at the previously mentioned commercial farms. The summer period was selected since deficit irrigation was applied to all crops at this time, and the differences between CT and RDI treatments were at their greatest. This is important since electrical resistivities of soils depend on amounts of water and dissolved ions present in the pores [26]. The ERT campaigns were performed in one of the irrigation lines along the 15 trees in the central row of each plot.

Data obtained were analyzed with all erroneous values first removed before inversion in the PROSYS software. Data were subsequently processed by the RES2DINV software, which runs an inversion process based upon the smoothness-constrained least-squares method in order to obtain a 2D distribution of electrical resistivity. Thus, the 2D distribution is related to physical properties of the subsurface named as an inverted resistivity image or 2D resistivity section [27]. The accuracy of the inversion model of each section was characterized by its root-mean-square (RMS) error value $[13,28]$. The inversion software (RES2DINV) divided the subsurface into rectangular pixels with each of them taking a 
singular resistivity value according to the material present in it. ERT resolution depends on electrode spacing and resistivity contrast; vertical resolution decreases as depth increases [29]. In our study, the pixel width was $0.15 \mathrm{~m}$ and the vertical pixel dimension was around $0.16 \mathrm{~m}$. Pixel shape achieved in this study was sufficient to distinguish property changes at shallow depths [30]. Figure 3 shows data numbers (700 data points) obtained in one electrical tomography profile.

\section{ERT profiles}

Syscal-R1 switch resistivimeter 36 electrodes spaced $30 \mathrm{~cm}$

Wenner-Schlumberger electrode array

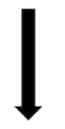

\section{Data processing}

Smoothness-constrained least-squares method

2D distribution of electrical resistivity

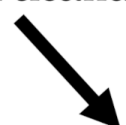

\section{Soil sampling}

Two depths $(30$ and $70 \mathrm{~cm}$ ) 84 soil samples

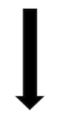

Laboratory analysis

Soil moisture, $\mathrm{pH}$, electrical conductivity, texture, organic carbon, soluble cations $\left(\mathrm{Na}^{+}, \mathrm{Ca}^{2+}, \mathrm{K}^{+}\right.$and $\mathrm{Mg}^{2+}$ and anions $\left(\mathrm{NO}^{3-}, \mathrm{Cl}\right.$-and $\left.\mathrm{SO}_{4}{ }^{2-}\right)$

\section{Modelling and validation \\ Nonlinear regression analysis}
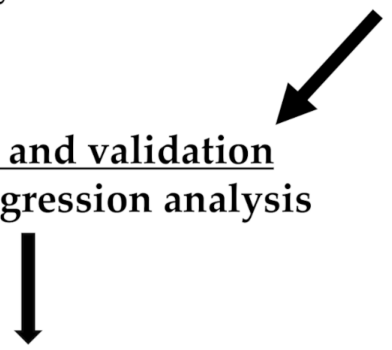

Final result

2D distribution of soil moisture

Figure 2. Scheme of the methodology applied in our study.

SATURN PEACH RD

ARRANGEMENT OF MODEL BLOCKS AND APPARENT RESISTIVITY DATUM POINTS

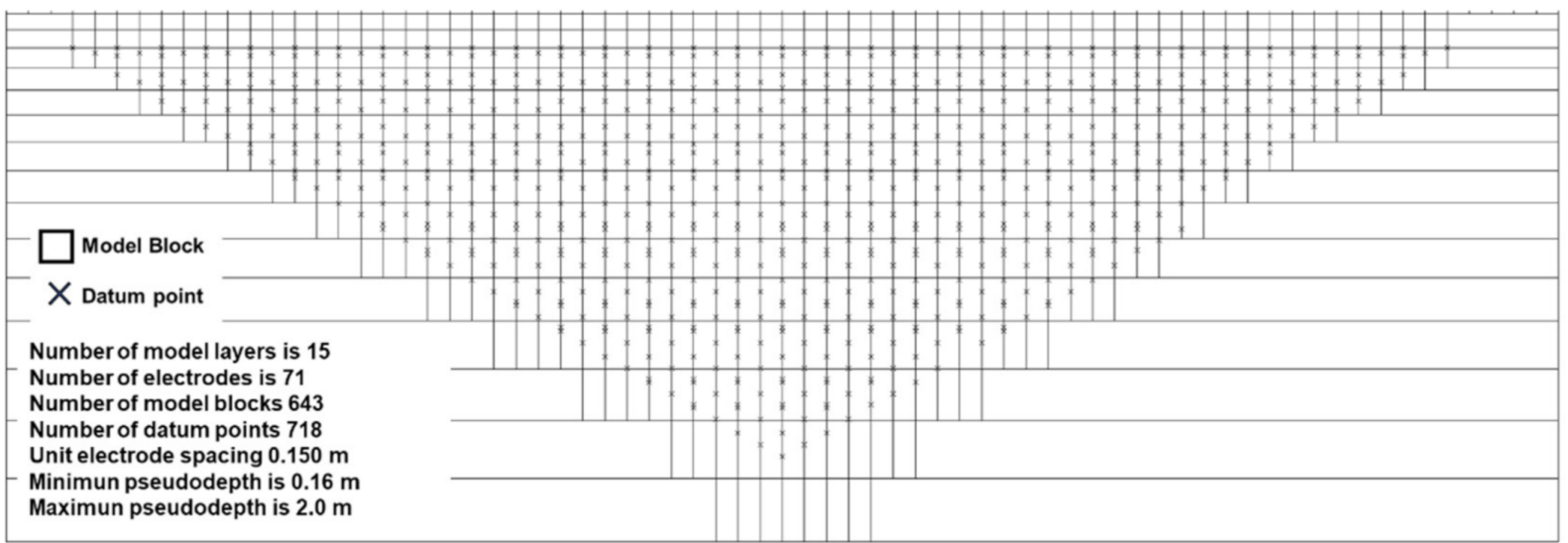

Figure 3. Arrangement of electrodes for a 2D electrical survey and pseudosection data patterns for the Wenner-Schlumberger arrays.

\subsection{Soil Sampling and Analytical Methods}

Immediately after the ERT campaigns, soil samples were collected along the ERT profiles at different electrode positions at two different depths $(0-30 \mathrm{~cm}$ and 0-70 cm). A total of 84 soil samples were collected, 12 for each crop type and year. Soil samples were collected with an auger hole. For each depth, soil was introduced into a polyethylene bag and mixed, after which samples were transported to the laboratory where oven-drying was applied for $48 \mathrm{~h}$ at $45^{\circ} \mathrm{C}$. Samples were passed through a 2-millimetre sieve for analyses. 
Soil moisture was measured in situ using a ProCheck and 5TM sensors (Decagon Devices, Pullman, WA, USA). Soil pH and electrical conductivity (EC) were measured in deionised water (1:1 and 1:5 $w / v$, respectively). Soil texture was measured from a soil/Napolyphosphate extract and determined using laser diffraction (Mastersizer 2000, Malvern Panalytical, Malvern, UK). Soil organic carbon (SOC) was determined using the dichromate oxidation method [31], $\mathrm{CaCO}_{3}$ was determined using the Bernard's calcimeter and total nitrogen (NT) was determined using the Kjeldahl method [32]. Soluble cations $\left(\mathrm{Na}^{+}\right.$, $\mathrm{Ca}^{2+}, \mathrm{K}^{+}$and $\left.\mathrm{Mg}^{2+}\right)$ and anions $\left(\mathrm{NO}_{3}{ }^{-}, \mathrm{Cl}^{-}\right.$and $\left.\mathrm{SO}_{4}{ }^{2-}\right)$ were extracted with deionized water $(1: 5 w / v)$. Anions were measured using ion chromatography (ICNet, Metrohm, Herisau, Switzerland), while cations were measured using atomic absorption spectrometry (AAnalyst 800, Perkin Elmer, Waltham, MA, USA).

\subsection{Data Analyses}

A Kolmogorov-Smirnov normality test at $p<0.05$ was used to ensure normality in fitting the data. No normal distribution of data was achieved even after log-transformation. Consequently, a Mann-Whitney $\mathrm{U}$ test at $p<0.05$ was performed in order to assess significant differences among CT and RDI treatments for each variable. A Spearman correlation was carried out to establish relationships between electrical resistivity data and soil physicochemical properties. These statistical analyses were performed with the software IBM SPSS statistics v.23.

Some studies assess the relationship between moisture and resistivity applying Archie's laws; however, this is not recommended for soils with sand and coarse-sized materials content below $80 \%$ [9] or for heterogeneous soils $[13,15]$. Therefore, in our study a simple nonlinear regression analysis was carried out in order to obtain a model that allowed prediction of soil water content and soluble nutrients in crop fields based on electrical resistivity data. The selected response variable $(\mathrm{Y})$ was the soil water content or the contents of different cations and anions, while the soil resistivity or log-resistivity was used as the explanatory variable for prediction $(\mathrm{X})$. Of the total data, $67 \%$ were used as the calibration set, while the remaining $33 \%$ of the total data were used as the validation set. Outlier data were excluded from the analyses. Thus, 53 values were used for calibration and 31 values used for validation. Residuals from the calibrated models were satisfactory checked for the model assumptions of normality (Kolmogorov-Smirnov test), linearity and homocedasticity, and equations with $\mathrm{R}^{2}<0.6$ were rejected. In order to validate the models, residuals from the estimated variables of the validation set had to be within the confidence interval (CI) (at 95\%) of the residual distribution of the calibrated model. CI was calculated as \pm 1.96 standard deviations of the residuals in the calibrated model. Modelling was performed with the software SigmaPlot v.12 (Systat Software, Inc., San Jose, CA, USA).

\section{Results and Discussion}

\subsection{ERT Model}

We observed that log-resistivity was negatively and significantly correlated with soil moisture ( $\mathrm{R}=-0.545 ; p<0.05)$, $\mathrm{EC}(\mathrm{R}=-0.305 ; p<0.01), \mathrm{NO}_{3}{ }^{-}(\mathrm{R}=-0.295 ; p<0.01)$, $\mathrm{SO}_{4}{ }^{2-}(\mathrm{R}=-0.380 ; p<0.05)$ and $\mathrm{Mg}^{2+}(\mathrm{R}=-0.378 ; p$-value $<0.05)$. The negative correlation suggests that a high concentration of water and salts is followed by low values of electrical resistivity [14]. Nonetheless, correlation coefficients were low, indicating a lack of any strong linear correlations between electrical resistivity and other variables.

As a result of the simple nonlinear regression, multiple equations were obtained for each dependent variable. However, among all of them, only an exponential decay of a threeparameter equation between soil moisture and log-resistivity achieved all assumptions for model acceptance (residuals normality $(\mathrm{Z}=0.54 ; p<0.05)$, linearity and homoscedasticity, and $R^{2} \geq 0.6$ ) (Figure 4 ). The lack of any strong correlations between electrical resistivity and the different cations and anions hampered the calibration of suitable models. In this sense, soil moisture was the only variable that showed a strong correlation $(R>0.5)$ with resistivity. Hadzick et al. [33] were also able to calibrate ERT data with soil water content 
using regression equations, although in linear dependence. These authors reported that the accuracy of the regression model increased with increasing soil depth, showing values of $\mathrm{R}^{2}=0.4-0.6$ for $30 \mathrm{~cm}$ and $70 \mathrm{~cm}$ soil depths, similar to those obtained in this study for the exponential equation. Farzamian et al. [10] obtained moisture distribution maps from exponential equations obtained in a regression analysis comparing degree of saturation versus resistivity in unsaturated soils.

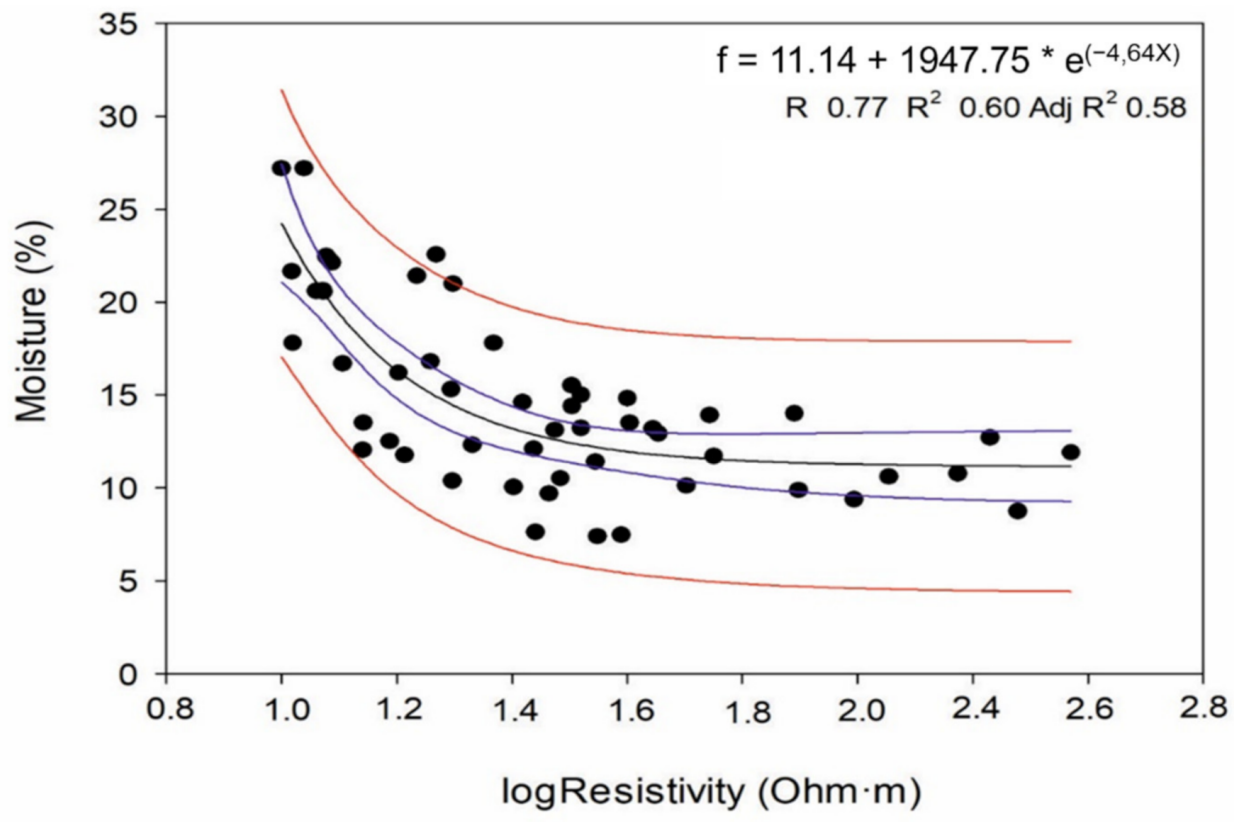

- log resistivity vs moisture —— 95\% Confidence Band _ - 95\% Prediction Band

Figure 4. Calibrated model (exponential decay of a three-parameter equation) for soil moisture estimation using the logarithm of electrical resistivity as the explanatory variable $(n=53)$.

The efficiency of the only model obtained by nonlinear regression analysis was validated by applying the exponential decay of a three-parameter equation to the validation set. This validation was shown by plotting the actual moisture values measured in farm soils and the moisture estimated with the model using the 31 validation samples (Figure 5). A total of $65 \%$ of the estimated data were within the CI (at 95\%), verifying good quality of the model. This methodology was similar to that used by other authors $[9,15,29]$ who also faced estimated and real moisture data in plots.

\subsection{Electrical Resistivity and Soil Moisture Imaging}

Resistivities are specific to each soil type, since they depend on several soil properties such as porosity, cation exchange capacity, organic matter content, salinity or clay content $[10,13,34]$. In order to ensure correct application of the model to all of the studied orchards, different soils were previously studied to select those orchards that reported similar soil properties. In order to avoid clay interferences with resistivity measurements, selected soils had to exhibit low clay contents, as can be seen in Table 1.

Inversion of measured resistivities is an essential step before interpretation of ERT profiles since apparent resistivity values rarely reveal the true structure of soils [15]. As a consequence, a 2D inversion was performed in this study using a cell-based model where the subsurface is subdivided into rectangular cells. The positions of the cells are fixed and only the resistivities of cells are allowed to vary during the inversion process, being the model parameter of the resistivity for each cell [20]. Hence, after a certain number of iterations, values of the interpreted resistivities and depths were obtained and plotted using the resistivity model (Figures 6-9). 


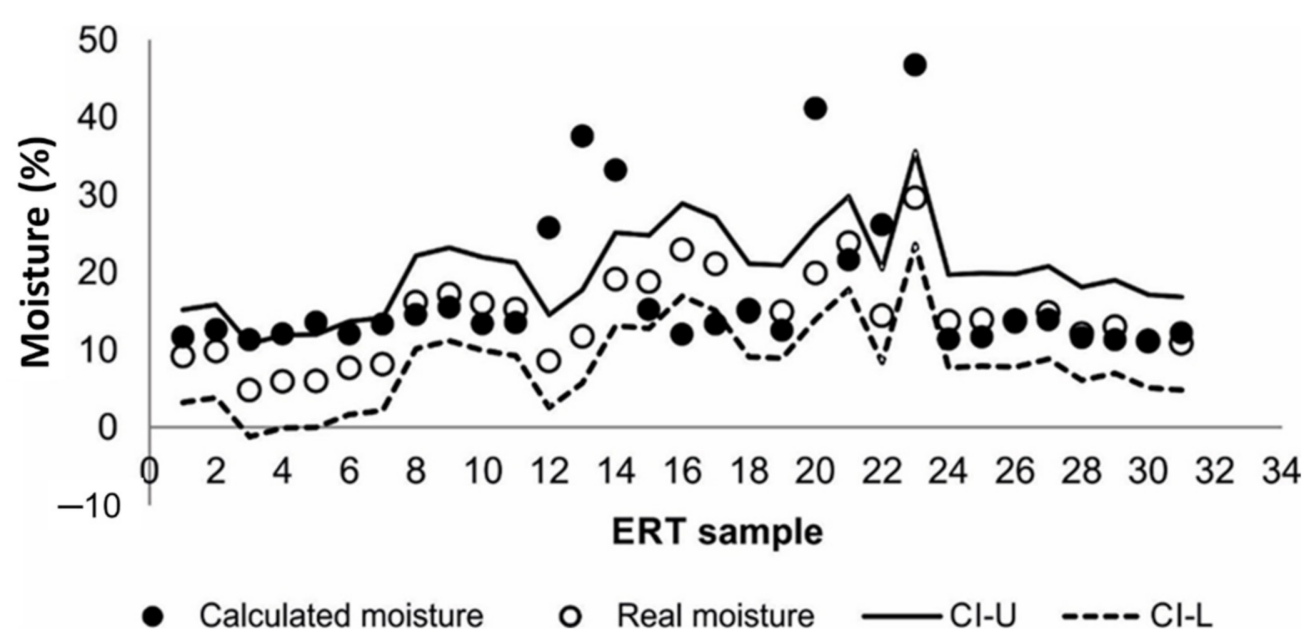

Figure 5. Relationship between real moisture and calculated moisture using the calibrated model (CI-U: upper limit of the confidence interval; CI-L: lower limit of the confidence level).

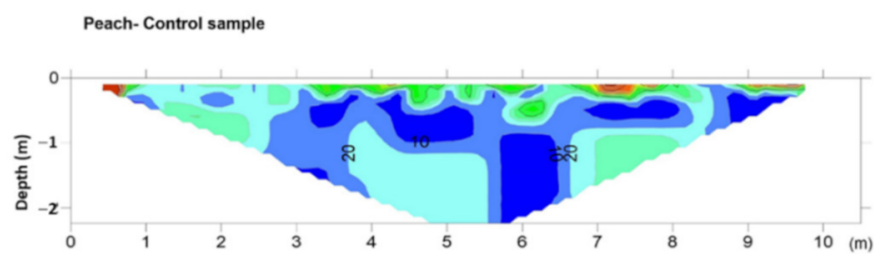

Peach- RDI sample

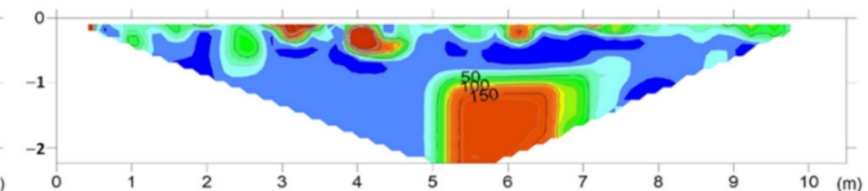

Resistivity (Ohm-m)

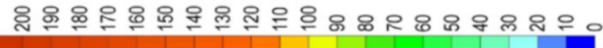
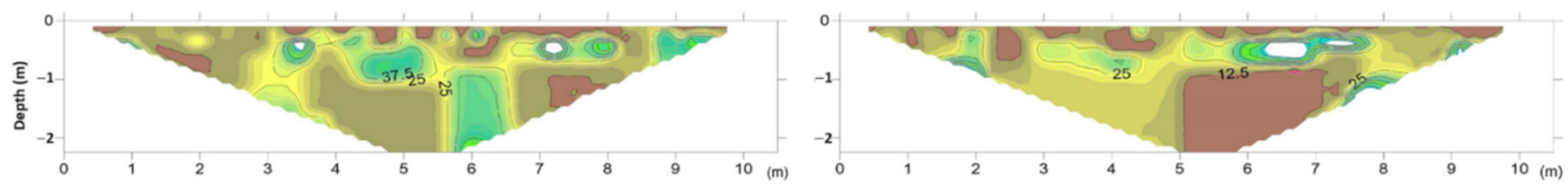

Moisture (\%)

Figure 6. Resistivity model (top) and predicted soil moisture (bottom) for control (left) and deficit irrigation (right) in the peach orchard.

The Mann-Whitney $\mathrm{U}$ test showed that there were significant differences $(p<0.05)$ between CT and RDI treatments for soil moisture, $\mathrm{Na}^{+}$and $\mathrm{Mg}^{2+}$. However, the 2D resistivity sections were only replaced by 2D soil moisture sections by application of the validated model (Figure 4) to all electrical resistivity values obtained with each ERT campaign (Figures 6-9). Note that white-coloured areas in the plots were considered outliers of the model developed since these data exceeded the calibration range of the model.

The expected relationship of resistivity and soil moisture is inverse, since reduction of the liquid phase decreases charge mobility (anions and electrons) [35] and should be strong enough to show variations in resistivity on the order of $10-100 \Omega \cdot \mathrm{m}$ between dry and moist soil [14]. Muñoz-Castelblanco et al. [36] found that variations in the degree of water saturation between $20 \%$ and $100 \%$ corresponded to variations in electrical resistivity between 100 and $10 \mathrm{Ohm} \cdot \mathrm{m}$ from resistivity data for loess at $1 \mathrm{~m}$ of depth $(\mathrm{e}=0.84$ and $\mathrm{e}=0.72$ ) and at $3.3 \mathrm{~m}$ of depth. Figure 6 shows the electrical resistivity and moisture sections for CT and RDI in the peach (P. persica) orchard. Variations in soil resistivity between CT and RDI profiles were attributed to variations in soil moisture since soil conditions and composition were the same in both profiles, except for the irrigation scheme used. Thus, 
the CT profile showed moderate values of resistivity $(\sim 50-70 \Omega \cdot \mathrm{m})$ in the first $30 \mathrm{~cm}$ of depth along the central part of the profile $(3-8 \mathrm{~m})$. This resistivity was associated with low water content $(8-12 \%)$, with opposite trends observed at the borders. Below $30 \mathrm{~cm}$ of depth, the section showed lower resistivity values $(\sim 0-10 \Omega \cdot \mathrm{m})$ with increased moisture values $(40-45 \%)$. There were furthermore two spots of moderate resistivity $(20-40 \Omega \cdot \mathrm{m})$ at $4 \mathrm{~m}$ and $7 \mathrm{~m}$ from the first electrode $(0 \mathrm{~m})$ and at depths of 1-2 $\mathrm{m}$, which were associated with moistures of $25 \%$.
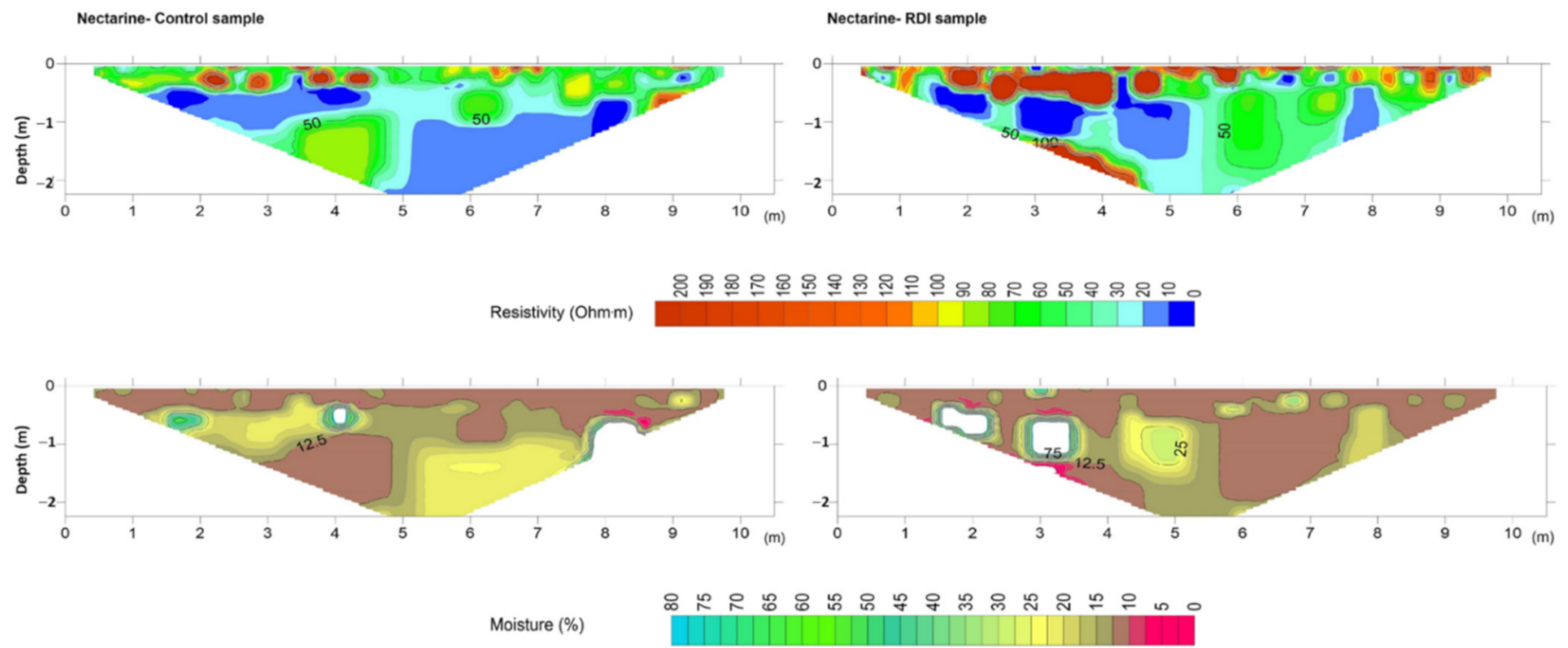

Figure 7. Resistivity model (top) and predicted soil moisture (bottom) for control (left) and deficit irrigation (right) in the nectarine orchard.
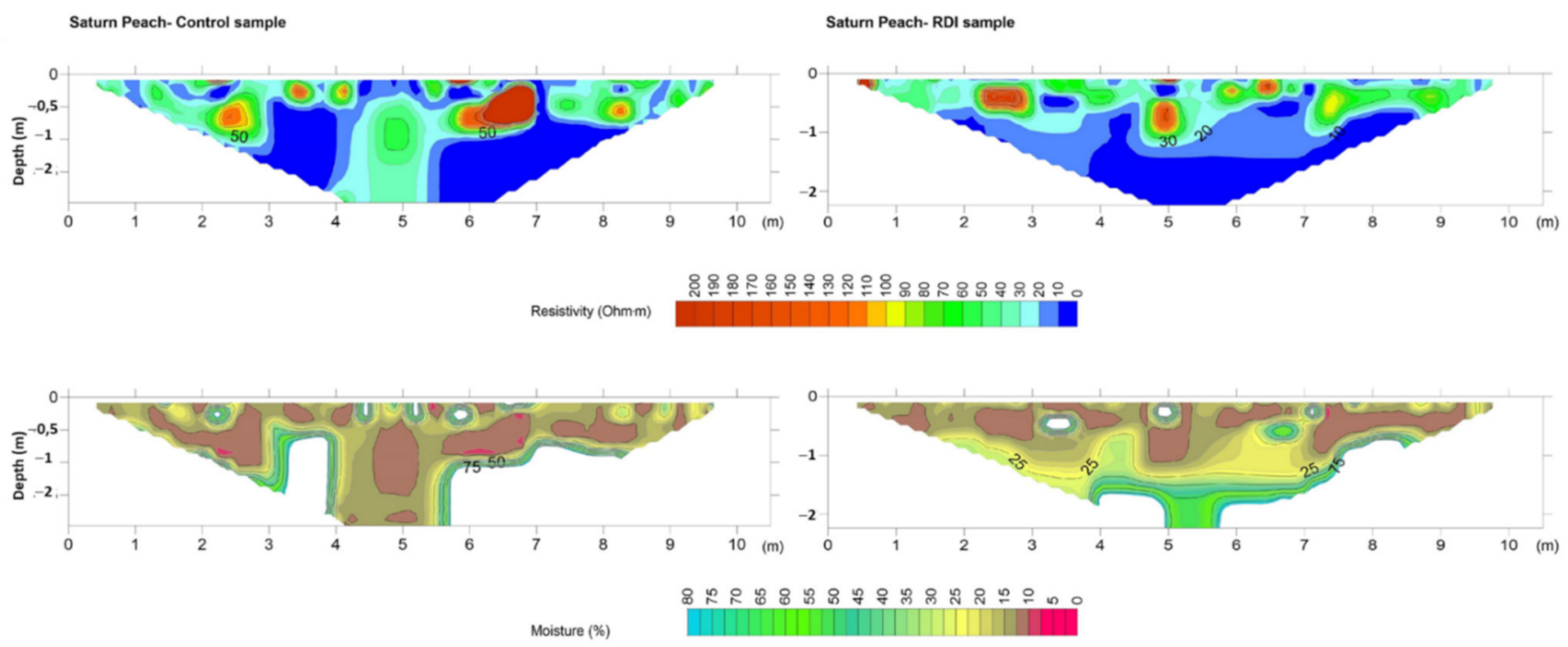

Figure 8. Resistivity model (top) and predicted soil moisture (bottom) for control (left) and deficit irrigation (right) in the Saturn peach orchard.

The distribution of resistivity throughout the RDI profile was more heterogeneous than in the CT profile from depths of $50 \mathrm{~cm}$. Resistivity reached values of $20 \Omega \cdot \mathrm{m}$ with some low resistive spots that were coincident with water accumulation areas $(25-50 \%$ of moisture). It is important to highlight the discordance of high resistivity $(>100 \Omega \cdot \mathrm{m})$ and low moisture values (0-10\%) observed for depths of 1-2 $\mathrm{m}$ and $6 \mathrm{~m}$ from the first electrode, which in the CT profile reported resistivity values next to zero. This suggests that under 
RDI water may be retained in soil sub-superficial layers (50-70 cm of depth), likely as a result of root action [37]. In this research, the ERT profiles were carried out very close to the trees, thus it is very likely that these anomalies resulted from the presence of roots. According to Giambastiani et al. [38], the presence of roots significantly affects ERT results; moreover, there are significant variations in resistivity ranges depending on the type of tree and on measurement conditions (wet or dry) [39-41].
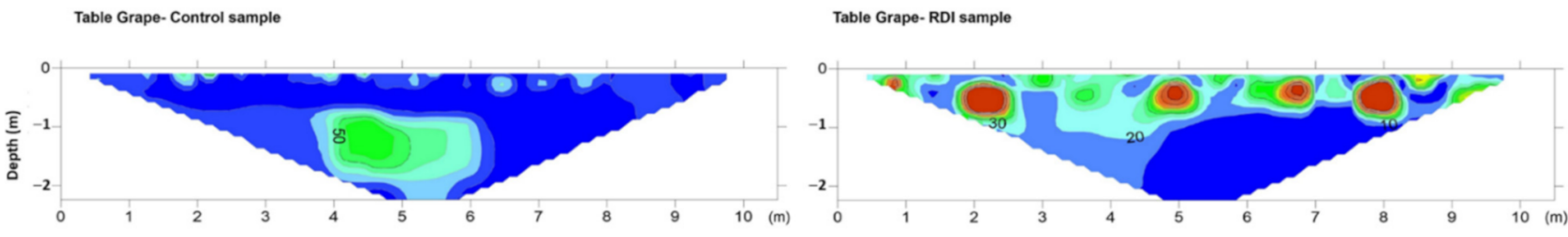

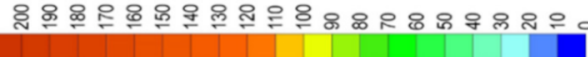

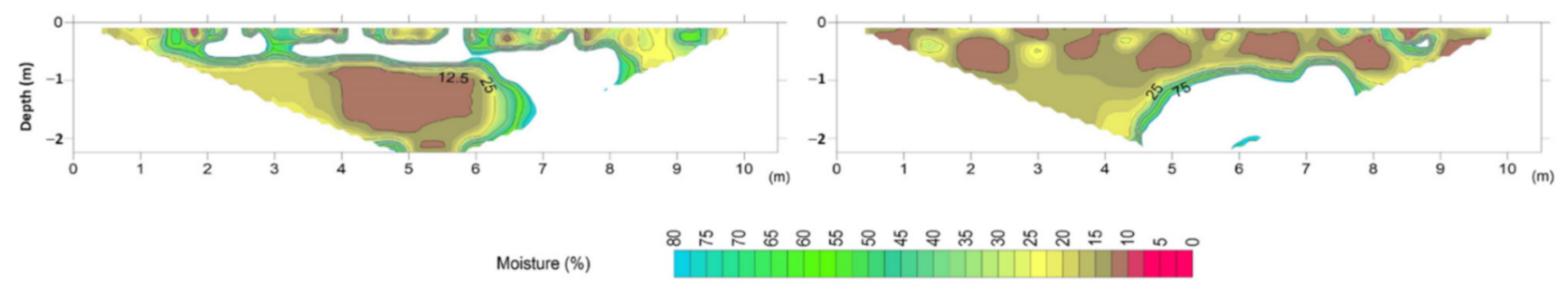

Figure 9. Resistivity model (top) and predicted soil moisture (bottom) for control (left) and deficit irrigation (right) in the table grape orchard.

In the nectarine (P. persica var. nucipersica) crop area the $\mathrm{CT}$ profile (Figure 7) revealed medium to high resistivity values $(60-90 \Omega \cdot \mathrm{m})$ at $30-50 \mathrm{~cm}$ depth with high resistive soil pockets $(>100 \Omega \cdot \mathrm{m})$ linked to low water content $(\sim 10 \%)$. In the RDI plot (Figure 7$)$, the subsuperficial soil layer $(30-50 \mathrm{~cm}$ depth) showed larger and deeper resistive areas $(>100 \Omega \cdot \mathrm{m})$ than those of the CT profile. These resistivity values were linked to moisture values $\leq 10 \%$. Furthermore, no percolation of water to deeper soil layers $(>1 \mathrm{~m})$ was observed. These observations suggest that in the CT crop where $100 \%$ of the water requirement was satisfied, a portion of the water was absorbed by trees while the rest percolated through the soil profile, reaching values of moisture close to $20 \%$. In RDI the irrigation water was mainly consumed by tree roots in sub-superficial layers. Discordances in resistivity and moisture values recorded at the borders of profiles are normally a result of the border effect of the ERT model [20].

Peach and nectarine crop areas were located in farms with similar soil clay contents, with values of $16 \%$ and $13 \%$, respectively; these could strongly affect resistivity values (Table 1). Despite both farms having very different salinity values between them (Table 1), $4.56 \mathrm{mScm}^{-1}$ in peach and $1.34 \mathrm{mScm}^{-1}$ in nectarine, the effect of electrical conductivity on resistivity values was not significant, since the correlation between EC and log-resistivity was low $(\mathrm{R}=-0.305 ; p<0.01)$ and it did not achieve all assumptions for model acceptance. Therefore, resistivity values were mainly affected by moisture content, where resistivities $>60 \Omega \cdot \mathrm{m}$ were associated with moisture contents of $\sim 12 \%$, while resistivities of $10-20 \Omega \cdot \mathrm{m}$ were linked to moisture contents of $25 \%$. Resistivity values $<10 \Omega$.m were associated with moisture contents of $40-45 \%$.

Saturn peach (Prunus persica var. platycarpa) showed moderate resistivity values $(20-50 \Omega \cdot \mathrm{m})$ at the borders and at the centre of the control pseudosection (Figure 8), and were linked to soil moisture values of $15-30 \%$. Moreover, some resistive soil spots $(90-100 \Omega \cdot \mathrm{m})$ were observed at depths of $0.5 \mathrm{~m}$ and $1 \mathrm{~m}$, and were linked to moisture values $<12 \%$. This suggests an effect in water movement by root water uptake [15]. In the RDI profile, low resistivity values $(<10 \Omega \cdot \mathrm{m})$ were more homogeneously present in areas below $50 \mathrm{~cm}$ depth; 
this was associated with a water content of $30 \%$. Moderately resistive soil was located over this area, showing soil pockets with high resistivities (up to $160 \Omega \cdot \mathrm{m}$ ) as a result of reduced water availability (10\% moisture) for tree roots. Since the amount of irrigation water was lower in RDI treatment than in CT, percolation of water and soil moisture content were lower in RDI than in CT (Figure 8). White areas in both control and RDI plots were outliers of the model.

Table grape (Vitis vinifera) showed homogeneous resistivity behaviour throughout the profile with a resistivity of $10 \Omega \cdot \mathrm{m}$ and moisture values close to $25-30 \%$, except on the soil surface where some soil pockets of low to medium resistivity $(20-30 \Omega \cdot \mathrm{m})$ were observed along with moisture values of 15-35\% (Figure 9). Note that along $50 \mathrm{~cm}$ of depth, a strip of zero resistivity was observed, extending to $2 \mathrm{~m}$ of depth at the right zone of the white-coloured subsection. In this area the moisture values were considered outliers of the model. Additionally, a higher resistive patch was observed 4-6 m from the first electrode with a meter of thickness from the first meter of depth, reaching values of $80 \Omega \cdot \mathrm{m}$ (moisture content $<12 \%$ ). Immediately below this strip, moisture values decreased from $90 \%$ to $12 \%$, indicating that no infiltration took place. The RDI profile (Figure 9) showed resistive soil spots $(>100 \Omega \cdot \mathrm{m})$ associated with moisture values close to $12 \%$. This behaviour was not observed in the CT profile, suggesting an absence of water percolating and powerful water uptake by grape roots.

\section{Conclusions}

The results showed that log-resistivity was negatively and significantly correlated with soil moisture, $\mathrm{EC}, \mathrm{NO}_{3}{ }^{-}, \mathrm{SO}_{4}{ }^{2-}$ and $\mathrm{Mg}^{2+}$; however, due to low values of their correlation coefficients $(R<0,55)$, only an exponential decay of the three-parameter equation between soil moisture and log-resistivity achieved all assumptions for model acceptance (residuals normality $(Z=0.54 ; p<0.05)$, linearity and homoscedasticity, and $\left.\mathrm{R}^{2} \geq 0.6\right)$. The model obtained allowed assessment of spatial variabilities of water content between irrigation schedules, showing differences between full irrigation (CT) and regulated deficit irrigation (RDI) among the different crops (Saturn peach, table grape, peach and nectarine). In the CT nectarine crop, results revealed that a portion of the irrigation water was absorbed by trees while the rest percolated through the soil profile in contrast with RDI where the irrigation water was mainly consumed by tree roots in sub-superficial layers. The ERT model has shown that under deficit irrigation situations, Saturn peach trees seem to uptake water from more distant locations from their root systems than when under full irrigation. At the same time, vertical water movement was not registered in RDI, contributing to water savings. The ERT model applied to the table grape orchard under the RDI regimen suggested an absence of water percolating and powerful water uptake by grape roots. Therefore, the ERT technique could be a useful and efficient tool for estimating soil moisture by calibration of empirical nonlinear regression models and for depicting different moisture zones through the soil profile, thereby avoiding aggressive measurements in the field. In addition, the results obtained from the model can be used to calculate soil-water related coefficients, such as water stress coefficients.

Author Contributions: Conceptualization, M.D.G.-L. and S.M.-M.; methodology, R.Z.; software, M.M.-S.; validation, M.M.-S.; formal analysis, R.Z.; investigation, J.A.A., M.M.-S. and R.Z.; resources, A.P.-P.; data curation, R.Z.; writing—original draft preparation, M.G. and R.Z.; writing—review and editing, J.A.A., M.M.-S. and S.M.-M.; visualization, M.M.-S.; supervision, Á.F.; project administration, A.P.-P.; funding acquisition, A.P.-P. All authors have read and agreed to the published version of the manuscript.

Funding: This research was funded by the European Union LIFE+ project IRRIMAN [LIFE13 $\mathrm{ENV} / \mathrm{ES} / 000539]$.

Informed Consent Statement: Not applicable.

Conflicts of Interest: The authors declare no conflict of interest. 


\section{References}

1. MAEC. Desertificación. Ministerio de Asuntos Exteriores; MAEC: Madrid, Spain, 2018.

2. Tomás, M.; Medrano, H.; Escalona, J.M.; Martorell, S.; Pou, A.; Ribas-Carbó, M.; Flexas, J. Variability of water use efficiency in grapevines. Environ. Exp. Bot. 2014, 103, 148-157. [CrossRef]

3. Hydrological Plan of the Segura River Basin. Memoria PHDS 2015/21. Confederación Hidrográfica del Segura, Ministerio de Agricultura, Alimentación y Medio Ambiente; Spanish Government: Madrid, Spain, 2015; p. 806.

4. $\quad$ Bastida, F.; Torres, I.F.; Romero-Trigueros, C.; Baldrian, P.; Vetrovsky, T.; Bayona, J.M.; Alarcon, J.J.; Hernandez, T.; Garcia, C.; Nicolas, E. Combined effects of reduced irrigation and water quality on the soil microbial community of a citrus orchard under semi-arid conditions. Soil Biol. Biochem. 2017, 104, 226-237. [CrossRef]

5. Fereres, E.; Soriano, M.A. Deficit irrigation for reducing agricultural water use. J. Exp. Bot. 2007, 58, 147-159. [CrossRef] [PubMed]

6. Medrano, H.; Tomas, M.; Martorell, S.; Flexas, J.; Hernandez, E.; Rossello, J.; Pou, A.; Escalona, J.M.; Bota, J. From leaf to whole-plant water use efficiency (WUE) in complex canopies: Limitations of leaf WUE as a selection target. Crop J. 2015, 3, 220-228. [CrossRef]

7. De la Rosa, J.M.; Conesa, M.R.; Domingo, R.; Torres, R.; Pérez-Pastor, A. Feasibility of using trunk diameter fluctuation and stem water potential reference lines for irrigation scheduling of early nectarine trees. Agric. Water Manag. 2013, 126, 133-141. [CrossRef]

8. Conesa, M.R.; Torres, R.; Domingo, R.; Navarro, H.; Soto, F.; Pérez-Pastor, A. Maximum daily trunk shrinkage and stem water potential reference equations for irrigation scheduling in table grapes. Agric. Water Manag. 2016, 172, 51-61. [CrossRef]

9. Brunet, P.; Clément, R.; Bouvier, C. Monitoring soil water content and deficit using Electrical Resistivity Tomography (ERT)—A case study in the Cevennes area, France. J. Hydrol. 2010, 380, 146-153. [CrossRef]

10. Farzamian, M.; Monteiro Santos, F.A.; Khalil, M.A. Application of EM38 and ERT methods in estimation of saturated hydraulic conductivity in unsaturated soil. J. Appl. Geophys. 2015, 112, 175-189. [CrossRef]

11. Michot, D.; Thomas, Z.; Adam, I. Nonstationarity of the electrical resistivity and soil moisture relationship in a heterogeneous soil system: A case study. Soil 2016, 2, 241-255. [CrossRef]

12. Brevik, E.C.; Fenton, T.E.; Lazari, A. Soil electrical conductivity as a function of soil water content and implications for soil mapping. Precis. Agric. 2006, 7, 393-404. [CrossRef]

13. Brillante, L.; Mathieu, O.; Bois, B.; van Leeuwen, C.; Lévêque, J. The use of soil electrical resistivity to monitor plant and soil water relationships in vineyards. Soil 2015, 1, 273-286. [CrossRef]

14. Alamry, A.S.; van der Meijdeb, M.; Noomenb, M.; Addinkc, E.A.; van Benthemc, R.; de Jong, S.M. Spatial and temporal monitoring of soil moisture using surface electrical resistivity tomography in Mediterranean soils. Catena 2017, 157, 388-396. [CrossRef]

15. Michot, D.; Benderitter, Y.; Dorigny, A.; Nicoullaud, B.; King, D.; Tabbagh, A. Spatial and temporal monitoring of soil water content with an irrigated corn crop cover using surface electrical resistivity tomography. Water Resour. Res. 2003, $39,1138$. [CrossRef]

16. Everett, M.E. Near-Surface Applied Geophysics; Cambridge University Press: Cambridge, UK, 2013.

17. Reynolds, J.M. An Introduction to Applied and Environmental Geophysics; Wiley-Blackwell: Oxford, UK, $2011 ;$ p. 712.

18. Martín-Crespo, T.; Gómez-Ortiz, D.; Martín-Velázquez, S.; Martínez-Pagán, P.; De Ignacio, C.; Lillo, J.; Faz, A. Abandoned Mine Tailings Affecting Riverbed Sediments in the Cartagena-La Union District, Mediterranean Coastal Area. Remote Sens. 2020, 12, 2042. [CrossRef]

19. Loke, M.H.; Barker, R.D. Least-square deconvolution of apparent resistivity pseudo-sections. Geophysics 1995, 60, 499-523. [CrossRef]

20. Loke, M.H. Tutorial: 2-D and 3-D Electrical Imaging Surveys; Geotomo Software: George Town, Malaysia, 2004.

21. IGME. Geological Map of Murcia Region Scale 1/200.000; IGME: Madrid, Spain, 2017.

22. IUSS Working Group. World Reference Base for Soil Resources. International Soil Classification System for Naming Soils and Creating Legends for Soil Maps; World Soil Resources Reports No 106; ISRIC World Soil Information: Wageningen, The Netherlands, 2014; p. 203.

23. Fereres, E.; Goldhamer, D.A. Suitability of stem diameter variations and waterpotential as indicators for irrigation scheduling of almond trees. J. Hortic. Sci. Biotechnol. 2003, 78, 139-144. [CrossRef]

24. Seidel, K.; Lange, G. Direct current resistivity methods. In Environmental Geology, Handbook of Field Methods and Case Studies; Knödel, K., Lange, G., Voigt, H., Eds.; Springer: Berlin/Heidelberg, Germany, 2007; pp. 205-238.

25. Acosta, J.A.; Martínez-Pagán, P.; Martínez-Martínez, S.; Faz, A.; Zornoza, R.; Carmona, D.M. Assessment of environmental risk of reclaimed mining ponds using geophysics and geochemical techniques. J. Geochem. Explor. 2014, 147, 80-90. [CrossRef]

26. Samouëlian, A.; Cousin, I.; Tabbagh, A.; Bruand, A.; Richard, G. Electrical resistivity survey in soil science: A review. Soil Tillage Res. 2005, 83, 173-193. [CrossRef]

27. Martínez-Pagán, P.; Faz, A.; Aracil, E.; Arocena, J.M. Electrical resistivity imaging revealed the spatial properties of mine tailing ponds in the Sierra Minera of Southeast Spain. J. Environ. Eng. Geophys. 2009, 14, 63-76. [CrossRef]

28. Ernstson, K.; Kirsch, R. Geoelectrical methods. In Groundwater Geophysics; Reinhard, K., Ed.; Springer: Berlin/Heidelberg, Germany, 2006; pp. 85-117.

29. Obi, J.C. The Use of Electrical Resistivity Tomography (ERT) to Delineate Water-Filled near a Bridge Foundation Recommended Citation. Master's Thesis, Missouri University of Science and Technology, Rolla, MO, USA, 2012. 
30. Anderson, N.; Apel, D.; Ismail, A. Assessment of Karst Activity at Construction Sites Using the Electrical Resistivity Method (Greene and Jefferson Counties, Missouri); University of Missouri: Rolla, MO, USA, 2006.

31. Soil Survey Staff. Soil Survey Field and Laboratory Methods Manual; Version No 2.0. USDA-NRCS. Soil Survey Investigations Report No 51; U.S. Government Publishing Office: Washington, DC, USA, 2014; p. 457.

32. Duchaufour, P. Precis de Pedologie; Masson: Paris, France, 1970; p. 438.

33. Hadzick, Z.Z.; Guber, A.K.; Pachepsky, Y.A.; Hill, R.L. Pedotransfer functions in soil electrical resistivity estimation. Geoderma 2011, 164, 195-202. [CrossRef]

34. Friedman, S.P. Soil properties influencing apparent electrical conductivity: A review. Comput. Electron. Agric. 2005, 46, 45-70. [CrossRef]

35. Cardoso, R.; Dias, A.S. Study of the electrical resistivity of compacted kaolin based on water potential. Eng. Geol. 2017, 226, 1-11. [CrossRef]

36. Muñoz-Casteblanco, J.; Pereira, J.; Delage, P.; Cui, Y. The influence of changes in wáter content on the electrical resistivity of a natural unsaturated loess. ASTM Geotech. Test. J. 2012, 35, 11-17.

37. Cassiani, G.; Boaga, J.; Vanella, D.; Perri, M.T.; Consoli, S. Monitoring and modelling of soil-plant interactions: The joint use of ERT, sap flow and eddy covariance data to characterize the volume of an orange tree root zone. Hydrol. Earth Syst. Sci. 2015, 19, 2213-2225. [CrossRef]

38. Giambastiani, Y.; Errico, A.; Preti, F.; Guastini, E.; Censini, G. Indirect root distribution characterization using electrical resistivity tomography in different soil conditions. Urban For. Urban Green. 2022, 67, 127442. [CrossRef]

39. Pawlik, L.; Ksprzak, M. Regolith properties under trees and the biomechanical effects caused by tree root systems as recognized by electrical resistivity tomography (ERT). Geomorphology 2018, 30, 1-12. [CrossRef]

40. Paglis, C. Application of electrical resistivity tomography for detecting root biomass in coffee trees. Int. J. Geophys. 2013, 2013, 383261. [CrossRef]

41. De Jong, S.M.; Heijenk, R.A.; Nijland, W.; van der Meijde, M. Monitoring Soil Moisture Dynamics Using Electrical Resistivity Tomography under Homogeneous Field Conditions. Sensor 2020, 20, 5313. [CrossRef] 